Jurnal PG-PAUD Trunojoyo : Jurnal Pendidikan dan Pembelajaran Anak Usia Dini, Volume 8, Nomor 1, April 2021 hal 66 - 78, ISSN : 2528-3553 (online), ISSN: 2407-4454 (print)

\title{
PENINGKATAN KEMAMPUAN MOTORIK KASAR MELALUI PENGEMBANGAN MODEL PERMAINAN SIRKUIT ANAK USIA 5-6 TAHUN
}

\author{
Fitta Nurisma Riswandi ${ }^{1}$ \\ ${ }^{1}$ Programstudi PIAUD, Institut Agama Islam Tribakti Kediri \\ Email: fiitanurisma@gmail.com
}

Received (Januari), Accepted (Maret), Published (April)

\begin{abstract}
Improvement of Gross Motor Skills through The Development of Circuit Game Models Ages 5-6 Years Old. The child's ability to perform gross motor movements is not yet optimal, the lack of variations in game models to encourage children to be more active, teachers are still not optimal in developing game models in gross motor activities, gross motor activities that are carried out are not well structured. The research objective was to obtain information about the needs of children's play models, the result was a circuit game model to improve children's gross motor skills which were feasible according to experts, and to test their effectiveness. This method uses Borg \& Gall development research with 9 steps. Collecting data through interviews, questionnaires for teachers, and children's observation sheets. This study uses time series design data analysis with graphs. The research shows that the results of the development of the circuit game model get the appropriate criteria according to the instrument expert with a score of 4 and the material expert with a score of 3.89 with very good criteria. It is stated that the circuit game model is effective and suitable for use after the initial trial, field test and operational field test with six treatments and an increase in each indicator. Operational field test results on the first treatment 14.38, second 17.42, third 18.81, fourth 19.23, fifth 19.23, and sixth 19.33 that the data is stationary or Ho is rejected. The conclusion is that the circuit game model is effective and feasible to be used by the teacher in improving the gross motor skills of children aged 5-6 years using the circuit game model.
\end{abstract}

Keywords: children aged 5-6 years, gross motor skills, circuit games

Abstrak: Peningkatan Kemampuan Motorik Kasar melalui Pengembangan Model Permainan Sirkuit Anak Usia 5-6 Tahun. Belum maksimalnya kemampuan anak dalam melakukan gerakan motorik kasar, minimnya variasi model permainan untuk mendorong anak lebih aktif bergerak, guru masih kurang optimal untuk mengembangkan model permainan dalam kegiatan motorik kasar, kegiatan motorik kasar yang dilakukan kurang terstruktur dengan baik. Tujuan penelitian untuk memperoleh informasi tentang kebutuhan model permainan anak, hasilnya adalah model permainan sirkuit untuk meningkatkan kemampuan motorik kasar anak yang layak menurut ahli, dan menguji keefektifannya. Metode ini menggunakan penelitian pengembangan Borg \& Gall dengan 9 langkah. Pengumpulan data melalui wawancara, angket untuk guru, dan lembar observasi anak. Penelitian ini menggunakan analisis data desain time series dengan grafik. Penelitian menunjukkan hasil pengembangan model permainan sirkuit mendapatkan kriteria layak menurut ahli instrument skor 4 dan ahli materi skor 3,89 dengan kriteria sangat baik. Dinyatakan model permainan sirkuit yang efektif dan layak digunakan setelah uji coba awal, uji lapangan, dan uji lapangan operasional dengan enam kali perlakukan dan mengalami peningkatan pada setiap indikatornya. Hasil uji lapangan operasional pada perlakuan pertama 14,38, kedua 17,42, ketiga 18,81, keempat 19,23, kelima 19,23, dan keenam 19,33 bahwa data bersifat stasioner atau Ho ditolak. Perolehan tersebut disimpulkan jika model permainan sirkuit efektif dan layak digunakan guru dalam peningkatan kemampuan motorik kasar anak usia 5-6 tahun dengan model permainan sirkuit.

Kata Kunci : anak usia 5-6 tahun, kemampuan motorik kasar, permainan sirkuit 
Jurnal PG-PAUD Trunojoyo : Jurnal Pendidikan dan Pembelajaran Anak Usia Dini, Volume 8, Nomor 1, April 2021 hal 66 - 78, ISSN : 2528-3553 (online), ISSN: 2407-4454 (print)

\section{PENDAHULUAN}

Perkembangan fisik menjadi salah satu masa periode perkembangan anak yang terlihat signifikan (Wahyudin \& Agustin, 2011). Hal ini menjadi dasar bagi kemajuan perkembangan selanjutnya yang juga dapat mempengaruhi perkembangan lainnya. Pernyataan tersebut juga didukung Piek, Dawson, Smith, \& Gasson (2008); Aye, Oo, \& Khin, Kuramoto-Ahuja, \& Maruyama (2017) bahwa pola perkembangan motorik anak sangat penting untuk fungsi perkembangan selanjutnya, sebab akan mempengaruhi kemampuan kognitif, sosial, dan emosional di masa selanjutnya. Hardy, King, Farrell, Macniven, \& Howlett, (2010); Cools, De Martelaer, Samaey, \& Andries (2009) menyatakan bahwa masa kanakkanak mengalami periode kritis dalam pengembangan keterampilan gerakan dasar, sehingga perlu aktivitas fisik yang dapat mendorong gaya hidupnya lebih aktif. Perkembangan yang ditandai dengan perkembangan motorik melalui kegiatan otot yang terkoordinasi, pusat saraf, dan urat saraf (Suyadi, 2010). Perkembangan fisik pada anak dapat diklasifikasikan menjadi dua yaitu fine muscle atau otot halus dan gross muscle atau otot kasar yang selanjutnya disebut motorik halus dan motorik kasar (Suyanto, 2005).

Motorik halus merupakan gerakan otot halus yang dipengaruhi adanya kesempatan belajar dan berlatih anak, sedangkan motorik kasar merupakan gerakan otot-otot besar yang dipengaruhi oleh kematangan anak (Adriani \& Bambang, 2012). Anak-anak prasekolah berada pada tahapan sudah mulai menemukan rasa sukacita dan kegembiraan saat melakukan aktivitas motorik kasar, dan pada saat yang bersamaan anak juga mungkin mendapatkan suatu sensasi kenikmatan dari penguasaan keterampilan otot kecilnya (Lindgren \& Watson, 1979). Perkembangan motorik kasar anak lebih berkembang terlebih dahulu daripada motorik halusnya. Terlihat dari anak memegang benda-benda berukuran besar terlebih dahulu dibandingkan benda yang ukuran kecil. Hal ini dikarenakan gerakan jari-jarinya belum mampu dikontrol anak dengan baik seperti pada kegiatan menggunting, meronce atau kegiatan lainnya.

Keterampilan motorik mendasar anak akan lebih berpeluang berkembang jika ada peningkatan aktivitas fisik (Colella \& Morano, 2011). Keterampilan gerakan dasar mencakup keterampilan lokomotor, manipulatif (kontrol objek) dan stabilitas (Hardy, King, Farrell, Macniven, \& Howlett, 2010). Keterampilan lokomotor (misalnya, berjalan, melompat dan lainnya) dan keterampilan kontrol objek (misalnya, menangkap, melempar dan menendang) (Cliff, Okely, Smith, \& McKeen, 2009). Jika keterampilan motorik anak ini tidak berkembang dengan baik maka akan memberikan dampak bagi perkembangan anak. Hal ini juga di dukung oleh Suyadi (2010) yang menyatakan bahwa anak akan merasa minder atau tidak percaya diri jika tidak memiliki keterampilan fisik motorik dengan baik.

Diperlukan suatu rancangan program latihan fisik dalam rangka untuk memantau perubahan yang terjadi pada anak seperti mengidentifikasi penundaan atau defisit perkembangan motorik, serta dapat membantu terapis fisik pada awal pengembangan keterampilan motorik kasar dimasa prasekolah ataupun sekolah dasar (Aye, Oo, \& Khin, 2017). Adanya program latihan fisik memiliki potensi untuk memungkinkan anak-anak berpartisipasi dalam permainan dan olahraga selama masa remaja dan dewasa, yang memungkinkan keterampilan tersebut dapat dipertahankan seumur hidup (Hardy, King, Farrell, Macniven, \& Howlett, 2010). Stimulasi aktivitas fisik ini dapat dilakukan melalui permainan yang melibatkan motorik kasar dan halus seperti kemampuan dalam mengontrol anggota tubuh, menjaga keseimbangan, koordinasi mata, kelincahan 
Jurnal PG-PAUD Trunojoyo : Jurnal Pendidikan dan Pembelajaran Anak Usia Dini, Volume 8, Nomor 1, April 2021 hal 66 - 78, ISSN : 2528-3553 (online), ISSN: 2407-4454 (print)

dan tangan serta yang lainnya (Fauziddin, 2014).

Seperti yang diketahui bahwa kebutuhan anak setiap hari yang mendasar adalah bermain. Anak dapat bermain merupakan hal yang sangat penting baginya, bukan sekedar penting saja tetapi perlu untuk difasilitasi agar pengalaman yang menyenangkan didapatkan oleh anak (Stone, 2017). Jika anak bermain maka perkembangan fisik motorik anak dalam menggerakkan tubuh akan menjadikan otot-otot anak kuat dan tubuh menjadi sehat (Tedjasaputra, 2001). Bermainnya seorang anak berarti anak sudah belajar sendiri dalam mencari sebuah pengetahuan dan pengalaman, sehingga tidak berlebihan jika permainan menjadikan sesuatu yang penting pada proses belajar anak pada pendidikan anak usia dini (Noorlaila, 2010). Oleh sebab itu, pemahaman orangtua maupun pendidik tentang anak usia dini sangat penting untuk dapat mengadakan suatu program pembelajaran yang terkait dengan unsur kegiatan bermain yang dapat disesuaikan dengan tahap tumbuh kembang anak. Seperti yang dinyatakan oleh (Siti \& Siregar, 2013) bahwa potensi anak dapat dikembangkan jika ada peran aktif dari orangtua dalam memahami tugas-tugas perkembangan anak dan memberikan pengasuhan serta pendidikan yang tepat.

Pada kenyataannya orangtua ataupun pendidik terlihat masih ada yang kurang memberikan stimulasi kegiatan bermain anak yang melibatkan motorik kasarnya. Padahal jika dilihat dari anak yang keterampilan motorik masih kurang akan menyebabkan kurang geraknya anak secara fisik dibandingkan dengan anak yang keterampilan motoriknya baik maka akan lebih aktif bergerak (Williams, Pfeiffer, O'neill, Dowda, McIver, Brown, \& Pate, 2008). Orangtua terkadang masih merasa enggan memberi kebebasan anak untuk dapat bermain di luar sehingga membuat orangtua merasa aman jika membiarkan anaknya bermain di dalam rumah dengan pengawasan. Apalagi saat ini sudah berada pada masa perkembangan teknologi yang maju sehingga sudah tidak asing lagi dikalangan anak. Mereka sudah mengenal namanya gadget seperti televisi, handphone (HP), laptop dan lainnya. Pengenalan gadget terhadap anak ini juga tidak terlepas adanya pengaruh dari lingkungan sekitarnya terutama orangtua. Seperti yang dijelaskan (Wijanarko, 2017) lebih dari $50 \%$ orangtua yang ada di Amerika Serikat mengakui bahwa menggunakan gadget sebagai alternatif mengasuh anak di saat orangtua sedang sibuk bekerja. Pendapat lain juga dinyatakan Tedjasaputra (2001) yang menyatakan bahwa anak menonton televisi akan lebih banyak mengalami peningkatan pada rentang usia 3-6 tahun Reilly, Jackson, Montgomery, Kelly, Slater, Grant, \& Paton, (2004) juga melaporkan bahwa anak usia 35 tahun menghabiskan 76-79\% berjam-jam di layar monitor dalam kegiatan menetap. Anak yang terlalu menghabiskan waktunya untuk bermain dengan gadget akan membuat anak kurang aktif dalam bergerak, sebab hanya terpaku pada layar. Pernyataan ini juga dijelaskan Anderson-McNamee \& Bailey, (2010) bahwa imajinasi anak akan lebih berkembang daripada gerakan fisiknya jika anak lebih banyak menghabiskan waktunya dengan menggunakan teknologi.

Apabila anak di rumah sering menggunakan gadget maka sebagai guru atau pendidik di sekolah seharusnya dapat menindaklanjuti dengan memberikan program pembelajaran yang berbasis bermain untuk dapat lebih melibatkan aktivitas fisiknya. Kegiatan bermain ini perlu dirancang guru dengan baik dan terstruktur. Salah satu alternatif permainan yang dapat dilakukan yaitu permainan sirkuit. Jenis permainan yang mengadopsi dari latihan sirkuit. Latihan ini memiliki bentuk-bentuk latihan yang dikombinasi dari semua unsur fisik, biasanya disusun dalam bentuk seperti lingkaran, sehingga dinamakan latihan sirkuit (circuit training) (Muhajir, 2007). Latihan sirkuit bertujuan untuk meningkatkan kebugaran jasmani. Kebugaran jasmani yang berkaitan dengan 
Jurnal PG-PAUD Trunojoyo : Jurnal Pendidikan dan Pembelajaran Anak Usia Dini, Volume 8, Nomor 1, April 2021 hal 66 - 78, ISSN : 2528-3553 (online), ISSN: 2407-4454 (print)

keterampilan (kebugaran motorik) yaitu keseimbangan, kelincahan, koordinasi, daya ledak, dan kecepatan (Suharjana, 2013). Jadi dapat dinyatakan bahwa permainan sirkuit merupakan beberapa unsur-unsur motorik kasar yang dirangkaikan dalam suatu permainan.

Beberapa rangkaian permainan sirkuit harus terdiri dari beberapa cakupan gerakan seperti pembentukan otot, baik menggunakan gerak dasar nonlokomotor, lokomotor dan manipulatif. Hal ini sesuai dengan penelitian yang sudah dilakukan oleh Susanti (2014) tentang permainan sirkuit warna-warni ceria yang dikembangkan untuk meningkatkan aspek kebugaran jasmani anak pada rentang usia 5-6 tahun. Permainan tersebut dimodifikasi secara menarik dengan memberi banyak warna agar menimbulkan ketertarikan dari anak dan kesenangannya dalam melakukan permainan yang memiliki 6 pos diantaranya untuk melatih: (1) kekuatan otot kaki serta keseimbangan (2) gerak dasar lokomotor melalui aktivitas terowongan warna-warni; (3) kelincahan dan gerak dasar lokomotor melalui aktivitas berlari zig-zag; (4) nonlokomotor dan kelenturan gerak anak melalui aktivitas selang warna-warni; (5) kemampuan ketepatan anak dan gerak dasar non-lokomotor melalui aktivitas bola gelinding; dan (6) keseimbangan dan mengembangkan kemampuan gerak dasar jalan melalui aktivitas berjalan seimbang.

Permainan sirkuit memiliki banyak manfaat bagi perkembangan anak. Tidak hanya perkembangan fisik motorik tetapi juga dapat meningkatkan perkembangan kognitif, bahasa, moral, dan sosial emosional. Untuk dapat melakukan permainan sirkuit perlu diperhatikan alat dan bahan yang dapat mendukung dalam permainan ini. Bahan dan alat yang digunakan juga disesuaikan dengan kebutuhan anak yaitu mudah, aman, dan disesuaikan dengan standar PAUD. Perlu untuk memperhatikan bahan dan alat yang digunakan dalam peningkatan kemampuan motorik kasar melalui permainan sirkuit yang terdiri dari beberapa unsur fisik.
Permainan sirkuit ini dilakukan diluar kelas (outdoor), dikarenakan permainan sirkuit membutuhkan tempat yang cukup luas sehingga adanya ruang gerak yang luas akan membuat anak dapat melakukan gerak dalam permainan ini dengan baik.

Terkait dengan hasil observasi dan wawancara pada 10 guru di 10 TK Kabupaten Nganjuk terdapat beberapa masalah yang terjadi. Hal ini dikarenakan: (1) kebutuhan bermain dalam peningkatan motorik kasar anak masih kurang diperhatikan guru, (2) kegiatan pembelajaran yang dilakukan guru terkait fisik motorik kurang menekankan pada kegiatan pembelajaran motorik kasar dibandingkan motorik halusnya, (3) kegiatan motorik kasar anak yang dilakukan guru masih monoton, (4) media yang digunakan masih kurang variatif, dan (5) kurang mengembangkan kegiatan motorik kasar berbasis permainan. Oleh sebab itu dibutuhkan suatu model permainan yang dapat menjadi alternatif jalan keluar dari permasalahan tersebut untuk dapat mengembangkan unsur-unsur motorik kasar yaitu koordinasi keseimbangan, kecpatan, daya ledak (power), serta kelincahan dan hal ini yang mendorong peniliti membuat penelitian pengembangan yang berbasis model permainan sirkuit anak untuk peningkatan kemampuan motorik kasarnya. Tujuan penelitian ini (1) Untuk memperoleh informasi tentang kebutuhan model permainan anak usia dini di TK usia 5-6 tahun. (2) Menghasilkan model permainan sirkuit untuk meningkatkan kemampuan motorik kasar anak usia 5-6 tahun yang layak menurut ahli. (3) Menguji keefektifan model permainan sirkuit untuk meningkatkan kemampuan motorik kasar.

\section{METODE}

Metode penelitian berupa penelitian pengembangan yaitu pendekatan penelitian dan pengembangan (Research and Development) yang sering dikenal dengan sebutan $R \& D$ atau diambil dari Borg and Gall (1983). Penelitian dan pengembangan 
Jurnal PG-PAUD Trunojoyo : Jurnal Pendidikan dan Pembelajaran Anak Usia Dini, Volume 8, Nomor 1, April 2021 hal 66 - 78, ISSN : 2528-3553 (online), ISSN: 2407-4454 (print)

$(R \& D)$ menggunakan sembilan langkah yaitu (1) Penelitian dan pengumpulan informasi di lapangan melalui studi lapangan/ wawancara dengan guru-guru di TK dan studi pustaka mengenai motorik kasar anak serta kendala yang dihadapi di lapangan. (2) Perencanaan, dalam melakukan analisis struktur isi, perumusan tujuan permainan, pengembangan instrumen kelayakan dan keefektifan produk menurut ahli materi dan ahli instrumen. (3) Mengembangkan bentuk awal produk yang berupa perencanaan draft awal produk dan validasi (4) Uji lapangan awal ada 6 anak di 1 TK Kabupaten Nganjuk. (5) Revisi produk awal setelah data didapatkan kemudian digunakan sebagai acuan serta produk divalidasi. Guru memvalidasi berdasarkan angket respon draf model permainan. Sebelum di uji cobakan ke lapangan utama, hasil validasi yang didapat digunakan untuk mengetahui kelayakan dan keefektifan model permainan sirkuit (6) Uji coba lapangan utama ada 30 di 5 TK Kabupaten Nganjuk menggunakan analisis times series. Uji coba ini menguji kelayakan dalam model permainan yang telah direvisi untuk meningkatkan kemampuan motorik kasar anak. Pengumpulan data hasil observasi, wawancara, dan angket kemudian dikumpulkan dan dianalisis (7) Revisi uji lapangan utama yaitu melakukan uji kelayakan desain maupun produk (8) Uji lapangan operasional ada 64 anak di 10 TK Kabupaten Nganjuk yang termasuk dalam uji coba terbatasdan uji coba lapangan utama. Tahap untuk melakukan uji kelayakan dan keefektifan pada model permainan sirkuit. Kemudian data hasil observasi, wawancara, dan angket dikumpulkan dan dianalisis peneliti. Uji coba ini menggunakan analisis time series (9) Penyempurnaan produk akhir. Sembilan tahapan perkembangan ini dianggap cukup untuk dapat melihat adanya pengaruh produk yang dikembangkan terhadap kemampuan motorik kasar anak usia 5-6 tahun. Tahap ini adalah tahapan akhir untuk melakukan penyempurnaan setelah adanya revisi sebelumnya.

\section{HASIL DAN PEMBAHASAN}

\section{A. Hasil Pengembangan Produk Awal} Hasil penelitian dari pengembangan ini bertujuan untuk menghasilkan peningkatan kemampuan motorik kasar anak usia 5-6 tahun melalui model permainan sirkuit. Hasil produk yang dihasilkan berupa pengemasan buku panduan untuk guru dari model permainan sirkuit. Pengembanga model permainan dinyatakan layak digunakan oleh ahli materi, dan guru. Tahapantahapannya sebagai berikut.

1. Analisis Kebutuhan

Kekurangan/ kendala yang terjadi dilapangan dapat dilakukan melalui analisis kebutuhan. Metode dalam pengumpulan data melalui observasi dan wawancara di 8 TK yaitu TK Kosgoro, TK ABA 3, TK ABA 5, TK Khadijah 1, TK Khadijah 3, TK Khadijah 4, TK AL Luqman Hakim, TK Islam Mutiara Bunda dan di 2 RA di RA Perwanida, RA Al Huda di Kabupaten Nganjuk. Metode observasi dan wawancara tersebut digunakan untuk melihat kondisi awal di lapangan. Berikut ini penjelasan lebih rincinya. Observasi dilakukan mulai bulan Februari 2018 melalui pengamatan peneliti selama 10 hari di 10 TK yang akan dijadikan penelitian.

Observasi yang dilakukan mulai dari anak masuk sampai bel pulang sekolah. Hasil pengamatan terlihat bahwa 5 TK dari 10 TK di pagi hari sebelum anak masuk ke dalam kelas terlebih dahulu melakukan kegiatan motorik kasar melalui senam pagi. Kemudian berlanjut dengan pembelajaran di dalam kelas sampai istirahat dan kembali masuk kelas untuk persiapan kegiatan selanjutnya, kemudian persiapan pulang sekolah. Berbeda halnya dengan 5 TK dari 10 TK tampak tidak melakukan kegiatan 
Jurnal PG-PAUD Trunojoyo : Jurnal Pendidikan dan Pembelajaran Anak Usia Dini, Volume 8, Nomor 1, April 2021 hal 66 - 78, ISSN : 2528-3553 (online), ISSN: 2407-4454 (print)

senam ataupun kegiatan yang menstimulasi motorik kasar anak sebelum masuk ke dalam kelas untuk persiapan pembelajaran. Hal ini terlihat bahwa hari senin dilakukan upacara sedangkan hari selasa atau jumat ada kegiatan keagamaan seperti hafalan surat pendek ataupun belajar sholat.

Data tersebut juga di dukung melalui wawancara terstruktur yang dilakukan di bulan Februari pada 10 guru di 10 TK didapatkan hasil 6 TK yang menyatakan bahwa pembelajaran yang dilakukan guru masih kurang menekankan pembelajaran motorik kasar daripada halus. Pernyataan guru tentang motorik kasar yaitu mudah dilakukan bagi anak, sedangkan motorik halus dapat mencakup semua aspek perkembangan anak, pembelajaran lebih banyak berada di dalam kelas, untuk persiapan masuk sekolah dasar, dan keterbatasan tempat untuk melakukan kegiatan motorik kasar. Berbeda dengan 4 TK lainnya yang menyatakan bahwa pembelajaran untuk kegiatan fisik motorik dilakukan secara seimbang. Hal ini di karenakan hampir setiap hari kegiatan motorik kasar maupun motorik halus sama-sama dilakukan. Jika motorik kasar sudah berkembang dengan baik maka baru muncul motorik halus.Sebab otot besar dulu yang dilatih baru otot kecil mengiri.

Kedua, semua TK menstimulasi kegiatan kemampuan motorik kasar anak dengan senam dan sedikit permainannya. Permainan yang sering dilakukan di semua TK seperti melempar sasaran, melompat, dan lempar tangkap bola. Adapun beberapa

permainan lainnya seperti bermain kucing-kucingan, lari memindahkan bendera, dan bakiak. Selain melakukan senam pagi dan permainan ada pula kegiatan lainnya yaitu melalui gerak dan lagu. Terkadang guru tidak memakai suara hanya gerakan sederhana yang dilakukan guru. Guru juga membenarkan jika kegiatan permainan yang mencakup lima unsur motorik kasar anak belum pernah dilakukan. Berdasarkan hasil wawancara 10 guru di 10 TK yang sangat membutuhkan kegiatan permainan dalam perkembangan motorik kasar yang mencakup 5 unsur sebanyak $70 \%$ dan 30\% lainnya membutuhkan permainan yang mencakup 5 unsur motorik kasar karena sudah pernah menerapkan permainan tetapi hanya mencakup 2 atau 3 unsur motorik kasar.

Ketiga, untuk menstimulasi kegiatan motorik kasar di $10 \mathrm{TK}$ memiliki caranya masing-masing yaitu ada 4 TK melakukan kegiatan senam pagisetiap 5 kali dalam seminggu, dan kegiatan permainan dilakukan ada yang 1 kali atau 2 kali seminggu. Berbeda dengan 6 TK yang melakukan senam 2 kali dalam seminggudan permainan dilakukan ada yang 1 kali atau 2 kali seminggu.

Keempat, media yang sering digunakan untuk kegiatan motorik kasar anak di semua TK yaitu Compact Disk (CD), dan bola.Adapun media lainnya yaitu tali, bendera, dan simpai. Media-media ini digunakan sebagai pendukung kegiatan motorik kasar yang diberikan kepada anak

Kelima, ada beberapa kesulitan kemampuan motorik kasar yang dialami anak yaitu melempar sasaran, lempar tangkap bola, melompat ataupun meloncat, menjaga keseimbangan tubuh, merayap, memanjat, dan bergelantungan. Aktivitas tersebut dilihat dari 5 TK yang kemampuan motorik kasar anak dalam melempar sasaran masih kurang terarah, 2 TK menyatakan motorik kasar kurang dalam lempar 
Jurnal PG-PAUD Trunojoyo : Jurnal Pendidikan dan Pembelajaran Anak Usia Dini, Volume 8, Nomor 1, April 2021 hal 66 - 78, ISSN : 2528-3553 (online), ISSN: 2407-4454 (print)

tangkap bola, 5 TK juga menyatakan bahwa kemampuan dalam melompat/ meloncat kurang berkembang baik, 1 TK menyatakan kemampuan motorik kasar anak kurang dalam menjaga keseimbangan tubuh, merayap, memanjat dan bergelantungan. Berbeda halnya dengan 1 TK dari 10 TK yang menyatakan bahwa kemampuan motorik kasar anak berkembang baik dan semua anak bisa.

Hasil paparan di atas berdasarkan observasi dan wawancara terlihat bahwa peningkatan kemampuan motorik kasar anak kurang optimal dilakukan oleh guru, media yang digunakan kurang bervariasi, dan masih ada beberapa unsur motorik kasar anak yang kurang berkembang dengan baik seperti koordinasi anak dalam melempar sasaran, lempar tangkap bola, kekuatan dalam melompat ataupun meloncat, merayap, memanjat, bergelantungan dan keseimbangan dalam menjaga keseimbangan tubuh anak. Untuk itu dalam penelitian ini mengembangkan model permainan sirkuit agar kemampuan motorik kasar anak meningkat. Model permainan sirkuit dirancang untuk meningkatkan unsur-unsur motorik kasar menjadi satu rangkaian permainan yang terdiri dari 5 pos. Permainan ini disesuaikan dengan karakteristik dan kebutuhan anak usia usia 5-6 tahun.

2. Deskripsi Draf Produk Awal

Berdasarkan hasil dari analisis kebutuhan yang ada sehingga dihasilkan pengembangan model permainan sirkuit. Hasil analisis berupa draf awal adalah langkahlangkah permainan sirkuit yang kemudian dikemas berupa buku panduan. Buku panduan ini diberikan kepada guru sebagai pedoman pelaksanaan permainan sirkuit. Berikut deskripsi produk awal. a. Langkah-langkah permainan sirkuit

Pelaksanaan dilakukan dari mempersiapkan tempat bermain, alat permainan, kemudian kegiatan awal atau melakukan pemanasan, kegiatan inti mulai masuk pada permainan sirkuit. Permainan yang terdiri dari 5 pos kegiatan yaitu Pos 1 yaitu meniti papan titian. Kegiatan berjalan di atas papan titian dengan membawa beban yaitu 2 ember berisi bola, Pos 2 yaitu botol warna. Kegiatan berlari zig-zag, Pos 3 yaitu ring basket, Pos 4 yaitu engklek. Kegiatan meloncat dengan satu ataupun dua kaki, Pos 5 yaitu bendera. Kegiatan berlari cepat sejauh 20 meter Kegiatan untuk memasukkan bola ke dalam ring basket dan terakhir penutup/ pendinginan

b. Buku panduan

Buku panduan merupakan pedoman bagi guru untuk dapat menerapkan dan melaksanakan permainan sirkuit kepada anak.

3. Data Validasi dan Kelayakan Produk Awal

a. Validasi ahli

Hasil dari validasi oleh para ahli (instrument dan materi) dikumpulkan baik saran maupun komentar untuk memperbaiki produk yang akan dikembangkan. Hasil penilaian dianalisis dengan mengkonversikan ke skala likert. Berikut tabel konversi dari data kuantitatif ke data kualitatif dengan skala empat.

Tabel 1. Skala Empat Konversi Data Kuantitatif ke Data Kualitatif

\begin{tabular}{|c|c|}
\hline Interval Skor & Deskripsi \\
\hline$X \geq 3,25$ & Sangat Baik \\
\hline $3,25>X \geq 2,5$ & Baik \\
\hline $2,5>X \geq 1,75$ & Cukup \\
\hline$X \leq 1,75$ & Kurang \\
\hline
\end{tabular}


Jurnal PG-PAUD Trunojoyo : Jurnal Pendidikan dan Pembelajaran Anak Usia Dini, Volume 8, Nomor 1, April 2021 hal 66 - 78, ISSN : 2528-3553 (online), ISSN: 2407-4454 (print)

1) Validasi ahli instrumen

Berikut tabel hasil dari validasi ahli instrumen terhadap instrumen ahli materi dan validasi ahli instrumen terhadap instrumen angket respon guru.

Tabel 2. Hasil Validasi Ahli Instrumen terhadap Instrument Ahli Materi

\begin{tabular}{|c|c|c|c|}
\hline No & Indikator & Skor & Kriteria \\
\hline 1 & Isi Materi & 4 & Sangat Baik \\
\hline 2 & Kualitas instruksional & 4 & Sangat Baik \\
\hline 3 & Alat permainan & 4 & Sangat Baik \\
\hline & Rata-rata & 4 & Sangat Baik \\
\hline
\end{tabular}

Tabel 3. Hasil Validasi Ahli Instrumen terhadap Instrument Angket Respon Guru

\begin{tabular}{|c|c|c|c|}
\hline No & Indikator & Skor & Kriteria \\
\hline 1 & $\begin{array}{c}\text { Kualitas permainan dan } \\
\text { tujuan }\end{array}$ & 4 & $\begin{array}{c}\text { Sangat } \\
\text { Baik }\end{array}$ \\
\hline 2 & $\begin{array}{c}\text { Kualitas instruksional } \\
\text { Alat permainan }\end{array}$ & $\begin{array}{c}\text { Sangat } \\
\text { Baik }\end{array}$ \\
\hline 3 & 4 & $\begin{array}{c}\text { Sangat } \\
\text { Baik }\end{array}$ \\
\hline & Rata-rata & 4 & $\begin{array}{c}\text { Sangat } \\
\text { Baik }\end{array}$ \\
\hline
\end{tabular}

2) Validasi ahli materi

Berikut hasil validasi ahli materi terhadap draf model permainan sirkuit.

Tabel 4. Hasil Validasi Ahli Materi terhadap Draf Model Permainan Sirkuit

\begin{tabular}{|c|c|c|c|}
\hline No & Indikator & Skor & Kriteria \\
\hline 1 & Isi Materi & 3,7 & Sangat Baik \\
\hline 2 & Kualitas instruksional & 4 & Sangat Baik \\
\hline 3 & Alat permainan & 4 & Sangat Baik \\
\hline & Rata-rata & 3,78 & Sangat Baik \\
\hline
\end{tabular}

Pemerolehan skor rata-rata dari rerata ketiga indikator ini adalah 3,78 dengan kriteria sangat baik. Hasil dinyatakan layak oleh ahli materi untuk digunakan dengan perbaikan sesuai saran, sehingga bisa ke tahap uji coba terbatas.

\section{B. Hasil Uji Coba Produk}

1. Hasil uji coba terbatas

Uji coba terbatas dilakukan setelah melakukan validasi dan perbaikan saran dari ahli materi dan instrumen untuk menilai produk dari pengembangan model permainan sirkuit yang dikemas dalam buku panduan yang akan digunakan oleh guru dalam menerapkannya kepada anak. Uji coba terbatas dilakukan untuk mengetahui dan memperoleh gambaran mengenai model permainan sirkuit dalam meningkatkan kemampuan motorik kasar anak usia 5-6 tahun. Uji coba terbatas dilakukan di 1 TK dengan subjek penelitian 6 anak di TK Islam Mutiara Bunda selama enam kali pertemuan. Setiap pos permainan terdapat kriteria pencapaian yang berbeda-beda dan nilai yang diperoleh masing-masing anak selanjutnya akan di akumulasikan untuk menentukan kriteria tingkat keberhasilan kemampuan motorik kasar anak. Berikut tabel konversi dari data kuantitatif ke data kualitatif dengan skala lima terkait kriteria keberhasilan kemampuan motorik kasar anak

Tabel 5. Skala Lima Konversi Data Kuantitatif ke Data Kualitatif

\begin{tabular}{|c|c|}
\hline Interval Skor & Deskripsi \\
\hline $\mathrm{X}>17$ & Sangat baik \\
\hline $14<\mathrm{X} \leq 17$ & Baik \\
\hline $11<\mathrm{X} \leq 14$ & Cukup \\
\hline $8<\mathrm{X} \leq 11$ & Kurang \\
\hline $\mathrm{X} \leq 8$ & Kurang sekali \\
\hline
\end{tabular}

Berikut tabel hasil observasi kemampuan motorik kasar anak dari rata-rata keseluruhan pada pertemuan ke 1-6 dengan kriteria keberhasilannya.

Tabel 6. Hasil Uji Coba Terbatas Kemampuan Motorik Kasar

\begin{tabular}{|c|c|c|}
\hline Pertemuan Ke & $\begin{array}{c}\text { Uji Coba } \\
\text { Terbatas }\end{array}$ & Kriteria \\
\hline 1 & 14 & Cukup \\
\hline 2 & 16,67 & Baik \\
\hline 3 & 18 & Baik \\
\hline 4 & 19,33 & Sangat baik \\
\hline 5 & 19,33 & Sangat baik \\
\hline 6 & 19,50 & Sangat baik \\
\hline
\end{tabular}


Jurnal PG-PAUD Trunojoyo : Jurnal Pendidikan dan Pembelajaran Anak Usia Dini, Volume 8, Nomor 1, April 2021 hal 66 - 78, ISSN : 2528-3553 (online), ISSN: 2407-4454 (print)

Data yang ada di analisis dengan desain time series di Microsoft Excel. Berdasarkan hasil dari analisis desain maka dapat melihat data stasioner atau tidak stasioner. Untuk melihat kejelasan data stasioner dengan grafik trend. Grafik yang dibuat plot antara observasi dengan waktu. Jika hasil data terlihat varians konstan dan memiliki rerata, maka data tersebut dapat dikatakan stasioner. Berikut ini dapat dilihat grafik uji coba terbatas dari hasil ratarata pertemuan ke 1-6 sebagai berikut.

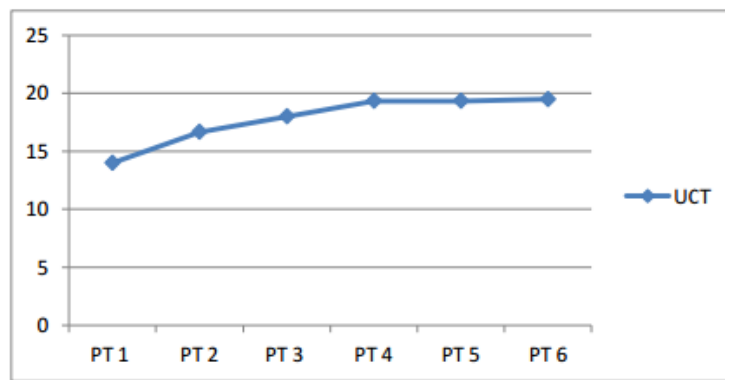

Gambar 1. Grafik Uji Coba Terbatas

Keterangan:

UCT : Uji Coba Terbatas

PT : Pertemuan

Berdasarkan dari tabel 6 terlihat hasil rata-rata pada pertemuan pertama adalah 14, pertemuan kedua naik menjadi 16.67, pertemuan ketiga naik menjadi 18 , pertemuan keempat naik menjadi 19.33, pertemuan kelima konstan atau tetap 19.33, dan pertemuan keenam naik menjadi 19.50. Perubahan data pertemuan keempat sampai keenam tidak terlalu signifikan sehingga data bersifat tetap/ konstan. Juga dapat dilihat dengan gambar grafik dari pertemuan kesatu sampai keempat ada kenaikan sedikit.

2. Hasil Uji Coba Lapangan

Tahap uji coba lapangan dilakukan setelah uji terbatas dan revisi produk kedua. Uji coba di 5 TK (TK Khadijah 3, TK Kosgoro, TK ABA 3, TK ABA 5, dan RA Al Huda) dengan subyek uji coba 30 anak. Berikut tabel hasil observasi kemampuan motorik kasar anak dari rata-rata keseluruhan pada pertemuan ke 1-6 dengan kriteria keberhasilannya..

Tabel 7. Hasil Uji Coba Lapangan Kemampuan Motorik Kasar

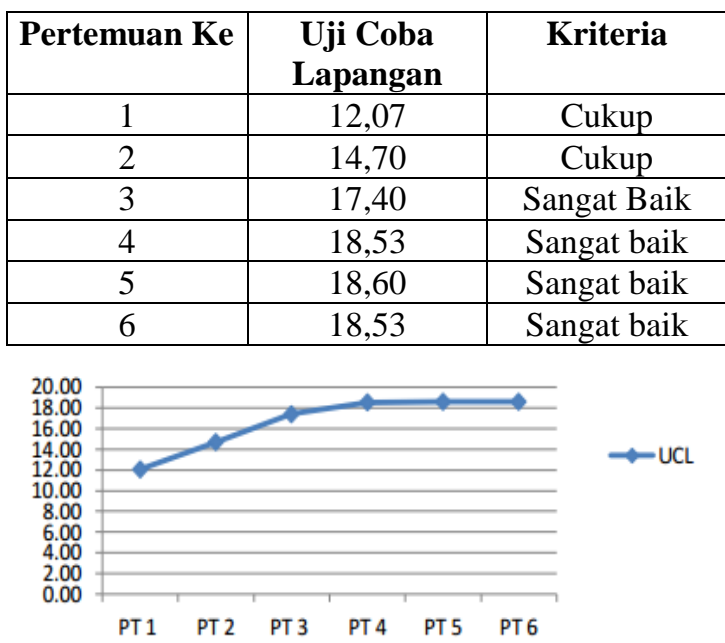

Gambar 2. Grafik Uji Coba Lapangan/ Diperluas

Keterangan:

UCL : Uji Coba Luas

PT : Pertemuan

Berdasarkan dari tabel 7 diperoleh rata-rata pada pertemuan pertama yaitu 12,07 , pertemuan kedua naik menjadi 14,70 , pertemuan ketiga naik menjadi 17,4 , pertemuan keempat naik menjadi 18,53 , pertemuan kelima naik menjadi 18,60 , dan pertemuan keenam sedikit menurun menjadi 18,53. Perubahan data pertemuan ketiga sampai keenam tidak terlalu signifikan sehingga data bersifat tetap/ konstan.

\section{Hasil Uji Coba Operasional}

Uji coba operasional setelah ada revisi produk kedua. Uji coba ini dilakukan di 10 TK (TK Islam Mutiara Bunda, TK Khadijah 3, TK Kosgoro, TK ABA 3, TK ABA 5, RA Al Huda, RAPerwanida, TK Khadijah 1, TK Khadijah 4, dan TK Al Luqman Hakim) dengan subyek uji coba 64 anak. Berikut 
Jurnal PG-PAUD Trunojoyo : Jurnal Pendidikan dan Pembelajaran Anak Usia Dini, Volume 8, Nomor 1, April 2021 hal 66 - 78, ISSN : 2528-3553 (online), ISSN: 2407-4454 (print)

tabel hasil observasi kemampuan motorik kasar anak dari rata-rata keseluruhan pada pertemuan ke 1-6 dengan kriteria keberhasilannya.

Tabel 8. Hasil Uji Coba Operasional Kemampuan Motorik Kasar

\begin{tabular}{|c|c|c|}
\hline $\begin{array}{c}\text { Pertemuan } \\
\text { Ke }\end{array}$ & Uji Coba Operasional & Kriteria \\
\hline 1 & 12,07 & Cukup \\
\hline 2 & 14,70 & Cukup \\
\hline 3 & 17,40 & Sangat Baik \\
\hline 4 & 18,53 & Sangat baik \\
\hline 5 & 18,60 & Sangat baik \\
\hline 6 & 18,53 & Sangat baik \\
\hline
\end{tabular}

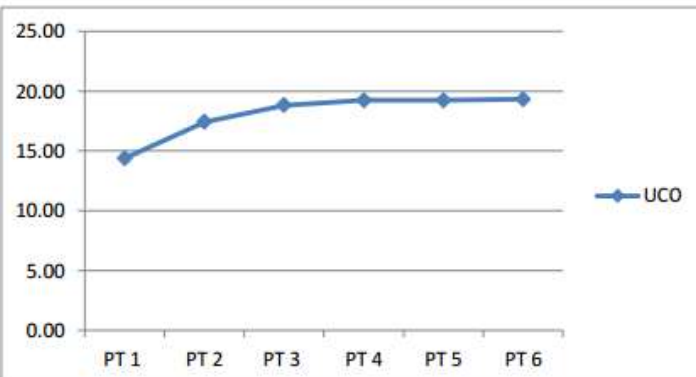

Gambar 3. Grafik Uji Coba Operasional

Keterangan:

UCO : Uji Coba Operasional

PT : Pertemuan

Berdasarkan dari tabel 7 diperoleh rata-rata pada pertemuan pertama sebanyak 14,38 , pertemuan kedua naik menjadi 17,42 , pertemuan ketiga naik menjadi 18,81 , pertemuan keempat naik menjadi 19,23, pertemuan kelima tidak ada perubahan yaitu tetap 19,23, dan pertemuan keenam naik menjadi 19,33. Perubahan data pertemuan ketiga sampai keenam tidak terlalu signifikan sehingga data bersifat tetap/ konstan Sehingga disimpulkan bahwa Ho ditolak atau data bersifat stationer atau tetap.

4. Hasil uji efektivitas

Uji efektivitas ini dilihat dari keefektifan produk yang dikembangkan. Produk yang dikembangkan dalam penelitian ini berupa draf model permainan sirkuit yang dikemas dalam buku panduan. Produk dinyatakan efektif jika dilihat dari kestasioneran data. Jika data yang diperoleh stasioner, maka dapat dinyatakan bahwa model permainan sirkuit efektif untuk meningkatkan kemampuan motorik kasar anak usia 5-6 tahun. Berdasarkan hasil yang diperoleh dari uji coba operasional terlihat bahwa data bersifat stasioner, sehingga dapat dinyatakan bahwa model permainan sirkuit efektif untuk meningkatkan kemampuan motorik kasar anak usia 5-6 tahun di TK Kabupaten Nganjuk.

\section{Revisi Produk}

\section{Revisi produk validasi}

Revisi produk validasi merupakan saran perbaikan dari ahli instrumen. Langkah-langkah permainan dan desain buku panduan permainan menurut ahli instrumen dan materi merupakan perbaikan revisi draf awal pengembangan model permainan sirkuit. Adapun perbaikan menurut ahli materi sebagai berikut.

Tabel 9. Indikator Pencapaian Pos 1

\begin{tabular}{|c|c|}
\hline Nilai & Indikator Pencapaian \\
\hline 1 & $\begin{array}{c}\text { Jika anak berjalan di atas papan titian } \\
\text { terjatuh berkali-kali }\end{array}$ \\
\hline 2 & $\begin{array}{c}\text { Jika anak berjalan di atas papan titian } \\
\text { terjatuh 2 kali }\end{array}$ \\
\hline 3 & $\begin{array}{c}\text { Jika anak berjalan di atas papan titian } \\
\text { terjatuh 1 kali }\end{array}$ \\
\hline 4 & $\begin{array}{c}\text { Jika anak berjalan di atas papan titian } \\
\text { terjatuh tidak terjatuh sama sekali }\end{array}$ \\
\hline
\end{tabular}

Tabel 10. Indikator Pencapaian Pos 2

\begin{tabular}{|c|c|}
\hline Nilai & Indikator Pencapaian \\
\hline 1 & $\begin{array}{c}\text { Jika anak berlari zig-zag dalam waktu 12-13 } \\
\text { detik }\end{array}$ \\
\hline 2 & $\begin{array}{c}\text { Jika anak berlari zig-zag dalam waktu 10-11 } \\
\text { detik }\end{array}$ \\
\hline 3 & $\begin{array}{c}\text { Jika anak berlari zig-zag dalam waktu 8-9 } \\
\text { detik }\end{array}$ \\
\hline 4 & $\begin{array}{c}\text { Jika anak berlari zig-zag dalam waktu 6-7 } \\
\text { detik }\end{array}$ \\
\hline
\end{tabular}


Jurnal PG-PAUD Trunojoyo : Jurnal Pendidikan dan Pembelajaran Anak Usia Dini, Volume 8, Nomor 1, April 2021 hal 66 - 78, ISSN : 2528-3553 (online), ISSN: 2407-4454 (print)

Tabel 11. Indikator Pencapaian Pos 3

\begin{tabular}{|c|c|}
\hline Nilai & Indikator Pencapaian \\
\hline 1 & $\begin{array}{c}\text { Jika anak melempar kantong biji sejauh } \\
250-300 \mathrm{~cm}\end{array}$ \\
\hline 2 & $\begin{array}{c}\text { Jika anak melempar kantong biji sejauh } \\
350-400 \mathrm{~cm}\end{array}$ \\
\hline 3 & $\begin{array}{c}\text { Jika anak melempar kantong biji sejauh } \\
450-500 \mathrm{~cm}\end{array}$ \\
\hline 4 & $\begin{array}{c}\text { Jika anak melempar kantong biji sejauh } \\
550-600 \mathrm{~cm}\end{array}$ \\
\hline
\end{tabular}

Tabel 12. Indikator Pencapaian Pos 4

\begin{tabular}{|c|c|}
\hline Nilai & Indikator Pencapaian \\
\hline 1 & Jika anakmeloncat sejauh $20-35 \mathrm{~cm}$ \\
\hline 2 & Jika anakmeloncat sejauh $40-55 \mathrm{~cm}$ \\
\hline 3 & Jika anakmeloncat sejauh $60-75 \mathrm{~cm}$ \\
\hline 4 & Jika anakmeloncat sejauh $80-95 \mathrm{~cm}$ \\
\hline
\end{tabular}

Tabel 13. Indikator Pencapaian Pos 5

\begin{tabular}{|c|c|}
\hline Nilai & Indikator Pencapaian \\
\hline 1 & $\begin{array}{c}\text { Jika anak berlari danmengambil bendera } \\
\text { dalam waktu 12-13 detik }\end{array}$ \\
\hline 2 & $\begin{array}{c}\text { Jika anak berlari danmengambil bendera } \\
\text { dalam waktu 10-11 detik }\end{array}$ \\
\hline 3 & $\begin{array}{c}\text { Jika anak berlari danmengambil bendera } \\
\text { dalam waktu 8-9 detik }\end{array}$ \\
\hline 4 & $\begin{array}{c}\text { Jika anak berlari danmengambil bendera } \\
\text { dalam waktu 6-7 detik }\end{array}$ \\
\hline
\end{tabular}

Sedangkan perbaikan pada buku panduan yaitu memperbaiki struktur dan format penulisan.

\section{Revisi produk tahap pertama}

Setelah revisi produk validasi oleh ahli materi tahap selanjutnya melakukan uji coba terbatas dan tahap ini merupakan revisi produk tahap pertama setelah uji coba terbatas dilakukan. Revisi produk ini dilakukan oleh 1 guru di TK Islam Mutiara Bunda. Adapun masukan dari guru untuk menyempurnakan produk yang dikembangkan. Berikut angket respon guru terhadap draf model permainan sirkuit pada uji coba terbatas sebagai berikut.
Tabel 14. Angket Respon Guru Terhadap Draf Model Permainan Sirkuit Pada Uji Coba Terbatas

\begin{tabular}{|c|c|c|c|}
\hline No & Nama & $\begin{array}{c}\text { Skor } \\
\mathrm{X}\end{array}$ & Kriteria \\
\hline 1 & $\begin{array}{c}\text { Guru Tk Islam Mutiara } \\
\text { Bunda }\end{array}$ & 4 & $\begin{array}{c}\text { Sangat } \\
\text { baik }\end{array}$ \\
\hline & Rata-rata & 4 & $\begin{array}{c}\text { Sangat } \\
\text { baik }\end{array}$ \\
\hline
\end{tabular}

Jika ahli praktisi/ guru telah memvalidasi draf model permainan sirkuit pada uji coba terbatasdan didapatkan rata-rata 4 serta dinyatakan sangat baik dan layak digunakan, maka dapat dilanjutkan ketahap uji coba lapangan/ diperluas dengan perbaikan sesuai saran dari ahli praktisi

\section{Revisi produk tahap kedua}

Setelah uji coba lapangan dilakukan adapun masukan dari guru untuk menyempurnakan produk yang dikembangkan. Adapun masukan yang diberikan kepada 5 guru di TK Khadijah 3, TK Kosgoro, TK ABA 3, TK ABA 5, dan RA Al Huda. Berikut hasil yang di dapat dengan kriterianya.

Tabel 15. Angket Respon Guru Terhadap Draf Model Permainan Sirkuit Pada Uji Coba Lapangan

\begin{tabular}{|c|c|c|c|}
\hline No & Nama & Skor X & Kriteria \\
\hline 1 & Guru Tk Khadijah 3 & 3,55 & Sangat baik \\
\hline 2 & Guru Tk Kosgoro & 3,73 & Sangat baik \\
\hline 3 & Guru Tk ABA 3 & 3,18 & Baik \\
\hline 4 & Guru Tk ABA 5 & 3,00 & Baik \\
\hline 5 & Guru RA Al Huda & 3,55 & Sangat baik \\
\hline & Rata-rata & 3,40 & Sangat baik \\
\hline
\end{tabular}

Jika ahli praktisi/ guru telah memvalidasi draf model permainan sirkuit pada uji coba lapangan dan didapatkan rata-rata 3,40 serta dinyatakan sangat baik dan layak digunakan, maka dapat dilanjutkan ketahap uji coba operasional dengan perbaikan sesuai saran dari ahli praktisi. 
Jurnal PG-PAUD Trunojoyo : Jurnal Pendidikan dan Pembelajaran Anak Usia Dini, Volume 8, Nomor 1, April 2021 hal 66 - 78, ISSN : 2528-3553 (online), ISSN: 2407-4454 (print)

\section{Revisi produk tahap ketiga}

Setelah uji coba operasional dilakukan adapun masukan dari guru untuk menyempurnakan produk yang dikembangkan. Masukan dari 10 guru di TK Khadijah 3, TK Kosgoro, TK ABA 3, TK ABA 5, RA Al Huda, RA Perwanida, TK Khadijah 1, TK Khadijah 4, TK Al Luqman Hakim, dan TK Islam Mutiara Bunda.

\section{Tabel 16. Angket Respon Guru Terhadap Draf Model Permainan Sirkuit Pada Uji Coba Operasional}

\begin{tabular}{|c|c|c|c|}
\hline No & Nama & $\begin{array}{c}\text { Skor } \\
\text { X }\end{array}$ & Kriteria \\
\hline 1 & Guru Tk Khadijah 3 & 3,55 & Sangat baik \\
\hline 2 & Guru Tk Kosgoro & 3,73 & Sangat baik \\
\hline 3 & Guru Tk ABA 3 & 3,18 & Baik \\
\hline 4 & Guru Tk ABA 5 & 3,00 & Baik \\
\hline 5 & Guru RA Al Huda & 3,55 & Sangat baik \\
\hline 6 & Guru RA Perwanida & 4,00 & Sangat baik \\
\hline 7 & Guru Tk Khadijah 1 & 3,45 & Sangat baik \\
\hline 8 & Guru Tk Khadijah 4 & 3,64 & Sangat baik \\
\hline 9 & $\begin{array}{c}\text { Guru Tk Al Luqman } \\
\text { Hakim }\end{array}$ & 3,55 & Sangat baik \\
\hline 10 & $\begin{array}{c}\text { Guru Tk Islam Mutiara } \\
\text { Bunda }\end{array}$ & 4,00 & Sangat baik \\
\hline & Rata-rata & 3,57 & Sangat baik \\
\hline
\end{tabular}

Jika ahli praktisi/ guru telah memvalidasi draf model permainan sirkuit pada uji coba lapangan dan didapatkan ratarata 3,57 serta dinyatakan sangat baik dan layak digunakan, maka dapat mengahsilkan produk akhir yang baik untuk digunakan.

\section{SIMPULAN}

Beberapa hal yang dibutuhkan dalam mengembangkan model permainan sirkuit usia 5-6 tahun yaitu (1) kegiatan permainan yang meliputi lima unsur aspek kemampuan motorik kasar, (2) model permainan disesuaikan pada tingkat pencapaian perkembangan anak khususnya pada lingkup perkembangan motorik kasar, dan (3) permainan sirkuit tidak hanya mencakup kemampuan motorik kasar tetapi aspek perkembangan lainnya.

Peningkatan kemampuan motorik kasar melalui pengembangan model permainan sirkuit anak usia 5-6 tahun yang layak menurut para ahli materi yaitu model permainan yang dikembangkan sesuai dengan tingkat usia anak 5-6 tahun. Hasil penilaian ahli materi mendapatkan kriteria sangat baik dengan skor rata-rata keseluruhan 3,78. Sehingga menunjukkan bahwa peningkatan kemampuan motorik kasar dapat meningkat melalui model permainan sirkuit yang dikemas dalam buku panduan layak digunakan untuk guru sebagai pedoman pelaksanaan permainan sirkuit untuk anak usia 5-6 tahun.

Penggunaan model permainan sirkuit efektif digunakan dilihat dari uji coba operasional pada 64 anak di 10 TK yang mendapatkan hasil data mengalami peningkatan dan stasioner. Demikian dapat disimpulkan bahwa pengembangan model permainan sirkuit efektif dalam peningkatan kemampuan motorik kasar anak usia 5-6 tahun.

\section{SARAN}

Pengembangan model permainan sirkuit untuk dapat meningkatkan kemampuan motorik kasar anak terutama usia 5-6 tahun dapat dikembangkan sendiri oleh praktisi/ guru, atau peneliti lain. Praktisi/ guru, atau peneliti lain dapat mengembangkan pada aspek lain seperti bahasa, moral agama, dan kognitif. Guru juga dapat memvariasikan kegiatan lain pada setiap pos.

\section{DAFTAR PUSTAKA}

Adriani, M dan Bambang W. (2012). Peranan Gizi dalam Siklus Kehidupan. Kencana Prenada Media Group. Jakarta.

Anderson-McNamee, J. K., \& Bailey, S. J. (2010). The importance of play in early childhood development. Montana State University Extention, 1-4

Aye, T., Oo, K. S., Khin, M. T., KuramotoAhuja, T., \& Maruyama, H. (2017). Gross motor skill development of 5year-old Kindergarten children in Myanmar. Journal of physical therapy science, 29(10), 1772-1778.

Borg, Walter R\& Gall, Meredith D. (1983). Education research:

an 
Jurnal PG-PAUD Trunojoyo : Jurnal Pendidikan dan Pembelajaran Anak Usia Dini, Volume 8, Nomor 1, April 2021 hal 66 - 78, ISSN : 2528-3553 (online), ISSN: 2407-4454 (print)

introduction ( $4^{\text {th }}$ ed). New York: Longman

Cliff, D. P., Okely, A. D., Smith, L. M., \& McKeen, K. (2009). Relationships between fundamental movement skills and objectively measured physical activity in preschool children. Pediatric exercise science, 21(4), 436-449.

Colella, D., \& Morano, M. (2011). Gross motor development and physical activity in kindergarten age children. International Journal of Pediatric Obesity, 6(sup2), 33-36

Cools, W., De Martelaer, K., Samaey, C., \& Andries, C. (2009). Movement skill assessment of typically developing preschool children: A review of seven movement skill assessment tools. Journal of sports science \& medicine, 8(2).

Fauziddin, M. (2014). Pembelajaran PAUD. Bandung: PT Remaja Rosdakarya

Hardy, L. L., King, L., Farrell, L., Macniven, R., \& Howlett, S. (2010). Fundamental movement skills among Australian preschool children. Journal of Science and Medicine in Sport, 13(5), 503-508

Lindgren, H. C., \& Watson, R. I. (1979). Psychology of the child and the adolescent. New York: Macmillan Public

Muhajir, (2007). Pendidikan Jasmani Olahraga dan Kesehatan Jilid 1. Jakarta: Erlangga

Noorlaila, I. (2010). Panduan lengkap mengajar PAUD. Yogyakarta: Pinus Book Publisher

Piek, J. P., Dawson, L., Smith, L. M., \& Gasson, N. (2008). The role of early fine and gross motor development on later motor and cognitive ability. Human movement science, 27(5), 668-681

Reilly, J. J., Jackson, D. M., Montgomery, C., Kelly, L. A., Slater, C., Grant, S., \& Paton, J. Y. (2004). Total energy expenditure and physical activity in young Scottish children: mixed longitudinal study. The Lancet, 363(9404), 211-212

Siti, N., \& Siregar, S. (2013). Persepsi orang tua terhadap pentingnya pendidikan bagi anak, 1(1), 11-27

Stone, S. J. (2017). The essential role of play in school contexts for the wellbeing of children. LEARNing Landscapes, 10(2), 305-318

Suharjana. (2013). Kebugaran Jasmani.Yogyakarta: Jogja Global Media

Susanti, R. A. (2014). Improvement of Physical Fitness Through Cheerful Colours Circuit Game. Jurnal Pendidikan Usia Dini, 8(2), 347358.

Suyadi. (2010). Psikologi belajar anak usia dini. Yogyakarta: PT Bintang Pustaka Abadi (BiPA).

Suyanto, S. (2005). Konsep dasar pendidikan anak usia dini. Jakarta: Departemen Pendidikan Nasional Direktorat Jenderal Pendidikan Tinggi Direktorat Pembinaan Pendidikan Tenaga Kependidikan dan Ketenagaan Perguruan Tinggi

Tedjasaputra, M. S.(2001). Bermain, mainan, dan permainan. PT: Gramedia Widiasarana Indonesia: Jakarta

Wahyudin, Uyu. \& Agustin, M. (2011). Penilaian perkembangan anak usia dini. Bandung: PT Refika Aditama

Wijanarko, J. (2017). Pengaruh pemakaian gadged dan perilaku anak, terhadap kemampuan anak taman kanakkanak happy holy kids Jakarta. Jurnal Institut Kristen Borneo, 2(1), 1-40

Williams, H. G., Pfeiffer, K. A., O'neill, J. R., Dowda, M., McIver, K. L., Brown, W. H., \& Pate, R. R. (2008). Motor skill performance and physical activity in preschool children. Obesity, 16(6), 1421-142 